\title{
İlhan Tekeli Düşüncesi: Çözüm Odaklı Bilgi Üretimi ve Yorumlama
}

\author{
Uğur Tanyeli ${ }^{1}$
}

“ilhan Tekeli düşüncesi” gibi bir ifade bir çarpıtma. Tümel yapıtı onlarca kitaptan, yüzlerce makaleden oluşan bir akademisyenin her yazdığını birbirine bağlayan tekil bir güzergahtan söz etmek düpedüz imkansız. Tek bir Tekeli düşüncesinden değil, farklı rotalarda ilerleyen Tekeli düşüncelerinden konuşmak gerekir. Dolayısıyla, Tekeli'nin ayrıntılı bir entelektüel biyografisini yazmak zorundayız. Onda Tekeli'nin yaşadığı ardzamanlı düşünsel değişimleri ve farklı bilgi alanlarına ilişkin yazdıklarındaki eşzamanlı çeşitlenmeleri birlikte çok karmaşık bir koreografik anlatı içinde ele almak aydınlatıcı olacaktır. Ne var ki, bu kısa makalede böyle bir deneme yapılmayacak; sadece bir tek düşünsel güzergaha ilişkin bir anlama denemesinde bulunulacak: Tekeli'nin modernleşme ve modernlik meselesi üzerindeki birkaç makalesini ele alacağım yalnızca.

Bence, İlhan Tekeli metinlerini okuyan birinin ilk farkına vardığı özellik, hiçbir metnin, araştırmanın ve argümanın sonuç üretmeksizin bırakılmamasıdır. Tekeli anlamak ve saptama yapmakla yetinmez; tartıştığ konuyu kuramsallaştırmakla kalmaz; ucu açık bırakmaz. Onun olası açıklamalar karşısında kararsız kalması da söz konusu değildir. Tekeli belirli bir mesele üzerine yazıyorsa mutlaka bir yanıtı vardır. Bu tavrı, olası veya aktüel bir imkana işaret etmek biçiminde somutlaşabilir, ama o asla bir çözümsüzlüğü, çelişkiyi, olanaksızlı̆̆ı ya da belirsizliği ortaya koyup yoluna devam etmez.

Bu yaklaşımının hem kişisel-biyografik, hem de toplumsal-tarihsel açıklamaları yapılmalıdır. İlki için lisans düzeyinde gördüğü mühendislik öğretiminin uzanımlarını dikkate almak anlamlı olabilir. Onun akademik öğrenim yaşamı araçsal düşüncenin cenneti olan inşaat mühendisliğinde başlar. Bu

\footnotetext{
${ }^{1}$ Prof. Dr., Dekan, İstanbul Şehir Üniversitesi, Mimarlık ve Tasarım Fakültesi, E-mail: ugurtanyeli@sehir.edu.tr
}

idealkent (c) Kent Araştırmaları Dergisi (Journal of Urban Studies) 
alan, sadece Türkiye için değil, dünya genelinde pratik-pragmatik bir düşünsel kararlılık kuvözüdür. Türkiye'de daha da fazla öyleydi; belki hala öyledir. Üstelik teknik düşünce burada onyıllar boyunca, kabaca 1940'lardan 2000'e kadar teknokratik alışkanlıklarla ittifak halinde olmuştu. Bilim ve teknolojinin dünyayı değiştiren temel dinamikler olduğu, onları vareden "yararlı insan"ın toplumsal mutluluk ve kurtuluşu sağlayacağı gibi argümanlarsa zaten daha 19. yüzyılın ikinci yarısından başlayarak yaygındı1. Hatta Türkiye'de 20. yüzyılın ikinci çeyreğinden itibaren bir tür gizli-Sensimonizm'in ya da daha doğrusu Saint-Simon'suz bir Sensimonizm'in inşası gerçekleştirilmiş gibi de gözükürr2 ${ }^{2}$ Mühendisler, bilim insanları, entelektüeller gibi modern araçsal bilgilerle donatılmış toplum gruplarının değişim ve atılım önderleri olarak nitelenmesine yaslanan bir tür ideolojik özgüven inşa edilmişti burada. Ülkeyi somut anlamda kuranlar, inşa edenler onlardı; yönetenler de onlar olmalıydı. Sözkonusu inancın herkesin bildiği pratik siyasal uzanımları vardır: 1960'lardan '80'lere, Demirel'den Özal'a dek ülkeyi epey ağırlıklı biçimde mühendisler yönettiler. Ancak, gündelik teknokratik politikanın dışındaki düşünce dünyasının rotaları içinde de mühendis egemenliğini farketmek zor değildi ${ }^{3}$. Aynı zihinsel çerçevede -yine St-Simon'dan habersiz, ama çok benzer bir yaklaşımla- din ile bilim çok pratik ve kolay biçimde buluşturulmuş gibiydi. Araçsallaştırılmış bilim Sağ' da da Sol'da da, ülkeyi karmaşık ve tehlikeli (çünkü tereddütler yaratan) düşünsel komplikasyonlarla karşllaşmadan dönüştürme iktidarında diye tahayyül edildi. Bunun özellikle Sağ için toplumsal değişimi ve gelişmeyi salt teknik bir mesele olarak tanımlama imkanı verişi nedeniyle yaşamsal bir "deus ex machina" olduğu söylenebilir. O sayede, teknik ve bilimin örneğin ne dinle, ne de mevcut geleneksel toplumsal yapılarla çelişmesi sözkonusuydu. Sol ise teknik ve bilimsel gelişmeden toplumsal değişime uzanan neredeyse mekanik bir süreç düşleyebildi. Teknoloji ve bilimsel düşünce aracıllğıyla toplum bir tür otomatizm içinde dönüşebilirdi.

Böyle bir iyimser ve naif siyasal-entelektüel ortamda Tekeli'nin mühendislikten toplumbilim ve tarihyazımına yumuşak geçiş yapması herhalde kolay olmuştu. Aynı bağlamda, toplumsallığa düzen getirmeye ve sonuç almaya odaklı bir yönelim geliştirmesi de şaşırtıcı olmasa gerek. Ancak, bu davranışının kökenlerini mühendislikte aramaya da gerek yok. Tanzimat sonrası Osmanlı/Türk düşünce tarihinde de başat olan, hemen daima çözüm merkezli konuşma güzergahlarıydı. Neredeyse her "okumuş"un elde ettiği bilgiyi işeyarar bir ilerleme ve dönüşüm aleti gibi değerlendirmeyi öngördüğü yüzyılı aşkın bir süreden söz edilebilir. Entelijensiyanın ülkeyi yöneten elitten özerk olmadığı, hatta tam örtüştüğü bu ortamda, kaçınılmaz olarak, 
modern bilginin bilmekten çok daha fazlasını yapabileceğine ve çözüm üreteceğine yönelik güçlü bir inanç egemendi. Bu, bilimle silahlanmış bir siyasal iktidar kavrayışı olarak nitelenebilirdi. Dahasını söylemek bile mümkün: Osmanlı/Türk entelijensiyası dünyayı anlamak, bilmek, yorumlamakla yetinmekten çok, bugünü ve geleceği yeniden biçimlemek, "memleketi kurtarmak" gibi somut hedeflere yönelik pratik amaçları olan bir epistemik rejim inşa etti. Entelijensiya yönetici elitle bütünleşik olduğu için, kendi rolünü de açık biçimde operasyonel nitelikte görüyor, yönetim işlevlerinin modernleştirilmesi aracilığıyla toplumun dönüştürülmesi dışında bir "kurtuluş" düşlemiyordu. Temel bilimlere (matematik, fizik, kimya, biyoloji) yönelik bugün bile devam eden ilgisizlik, işeyararlığı merkeze alan bu rejim için kaçınılmazd. "Soyut" bilginin değil, hemen kullanılarak geri kalmışlığı gidereceği umulan uygulamalı pratiklerin yüceltilmesi, çözüm merkezli düşünmenin olağan bir sonucudur.

İlginç olan, sosyal bilimlerin de ayn bilimciliğin (scientism) ve ayn toplumsal teknolojizmin (sosyal bilimlerin toplumu dönüştürme aracı olarak tahayyül edilmesi) bileşeni haline gelişidir. 1960'lardan sonra bile -hatta en fazla o dönemde- Niyazi Berkes gibi tarihçiler, İdris Küçükömer gibi iktisatçlar, Cavit Orhan Tütengil gibi sosyologlar, Doğan Avcıoğlu gibi gazeteciler böyle bir yaklaşımla ülkeyi dönüştürücü, sorun çözücü, gelişme önündeki engelleri teşhis ederek deva önerici düşünce adamları olarak çalışıyorlardı. İlhan Tekeli'nin o kuşağın ardılı olduğunu dikkate almak gerekir. Onların dünyasında işe başladı, onların mirasıyla beslendi ve giderek onların araçsal yaklaşımından epey uzaklaştı. Bu ortamda yetişmenin sonucu olarak, Tekeli'nin Osmanl1-Türkiye modernleşme tarihine birbiriyle sağlamca bağlantılı üç teşhis koyması galiba kaçınılmazdı: Zayıf Tarihsellik, Aydınlanma ve Modernite Projesi. Bunların üçü de açık veya örtük olarak eylem imkanları ve çözüm yolları tanımlayan teşhisler. Aşağıda kısaca tartışılacaklar.

\section{Zayıf Tarihsellik}

"Zayıf tarihsellik" Nilüfer Göle'nin icadı; ancak Tekeli'nin ayn "wording"le hiç kullanmadığı terim, onun historiyografik ve toplumbilimsel yorumlarının da anahtar kavramlarının başında geliyor. Göle bu kavramı sayısız kez tanımlamış ve kapsamını sürekli genişletmiş gözükür. Ancak, epey genelleyici tanımı, modernliğin içsel ve yerel bir süreç olarak ortaya çımadığı toplumların tarihsel değişimine işaret eder. Bu tür toplumlar kendi kendilerine, kendi tarihsel değişim serüvenleri bağlamında üretme iktidarında olmadık- 
ları modernliği Batı modernliği örneğinde inşa etmeye çabalarlar. Kendi tarihsel değişimleri, aslında "sağlam tarihsellik" ${ }^{4}$ toplumlarına ait olan modernleşme süreçlerini yaşamalarına imkan vermez; modernite onlara dışsaldır. O nedenle, aynı toplumun yönetici seçkinleri iradi olarak kendilerini d1şarıdan öğrendikleri moderniteye doğru yönlendirmeyi hedeflerler. Bunun Türkiye'de çok eskitilse de hala yaygın kullanımda olan "tepeden inme modernlik" gibi popüler tanımları vardır. Şöyle ki, zayıf tarihsellik "modernlik üretme özürlü" bu toplumda, zorunlu olarak küçük yönetici seçkinler grubunun modernlik açığını kapatmak için dışarıya sürekli müracaatını gerektirmiştir. Dolayısıyla temel argüman odur ki, modernite üretilmemiş, ithal edilip yukarıdan aşağıya empoze edilmiştir.

Terimin ifade ettiği ideolojik pozisyon, hemen daima tarihsel bir olanaksızlığa işaret eder: Osmanl1/Türk özne asla kapanmayacak bir modernlik aç1ğının kapatılmasıyla yükümlüdür. Yükümlülüğü Sisyphos'a biçilen mitolojik görev gibidir: Tanrı Hades ona bir tepeden aşağı yuvarlanan dev bir kayayı yeniden tepenin zirvesine taşıma cezası vermiştir; ne var ki kaya tam zirveye ulaştırıldığında yeniden aşağı yuvarlanmakta ve görev bitimsizce sürüp gitmektedir. İlginç olan şu: Osmanl//Türk modernleşmecilerinin grup kimlikleri inşa eden, toplumsal misyonlarını tarif eden de aynı olanaksız görevle "cezalandırılmalarıdır". Zayıf tarihsellik yaşayan bir toplumda onlar kazanılması imkansız savaşları verenler, ama asla yılmayan idealistlerdir. Çünkü Osmanlı kendi iç dinamikleriyle modernlik üretememiş, onu modernleştirici "kahramanlar" eliyle dışarıdan ithal zorunda kalmıştır. Bu ithalatın neden olduğu yabancılaşmaysa neredeyse son iki yüzyılı karakterize eder. Aynı süreçte hem o ithalata girişenler kendi toplumlarına yabancılaşırlar, hem de o toplum sürekli olarak yabancı bir metayı içselleştirmeye zorlanır. Değişim (ve daha şık deyimle modernleşme) böyle tarihselleştirilince, Osmanl1/Türk ortamında bir aydınlanma meselesi inşa etmek kaçınılmaz olur. Sorun şu ki, zayıf tarihsellik ortamında oldukları için kendi kendilerine aydınlanamayanları, pasif olanları, aktif seçkinlerin aydınlatması gerekir.

Bu akıl yürütme Türkiye modernleşmesinin sık sık eleştiri konusu yapılan tepeden inmeciliğine hem bir açıklama sunar, hem de gerekçe ve meşruiyet sağlar: Modernleştirici zorlamalar yaparak zayıf tarihsellikle yaralı bir toplumsallığa müdahale etmek zorunlu hele gelmiştir. "Aydınlanan (...) aydınlanmayı topluma götürme misyonunun yüklenmek"5 durumundadır. Bunun iki yüzyıl boyunca Osmanlı/Türk iktidar dilinin hep örtük bırakılmış, ama en bildik paradigmalarından biri olduğu söylenebilir. 
Bu noktada Tekeli'yi de aşacak kapsamda şu soruyu sormak gerekecek: Türkiye tarihinin gerçekten de toplumun kendi modernliğini üretme iktidarında olmadığı savı dışında açıklanması imkansız mı? Kuşkusuz mümkün. Ama bunun için modernliği Aydınlanma ile eşanlamlı kılmamak gerekir. Osmanlı toplumundaki değişimleri tüm toplumsal grupları ve tüm pratikleri içerecek kapsamda ve merkezi yönetimin eylemleriyle sınırlı olmayan çoğul bir çerçevede araştırmak, tarihselleştirmek ve kuramsallaştırmak gerekir. Ne var ki, Tekeli bunu yapmaz. Onun öncelikli hedefi gündelik yaşamdaki değişimler, estetik duyuşun başkalaşımı, din kavrayışının farklılaşması gibi, yönetilenlerin kendiliğinden vuku bulan dönüşümleri türünden konular olmaz. Onun bu doğrultuda araştırmaları yoktur. Tekeli yönetenlerin ve onlarla bütünleşik entelijensiyanın kendilerine 18. yüzyıldan beri dert bildikleri alanlardaki değişimleri araştırmayı yeğler. Bunun anlamı, modernleşmeyi "vatanı kurtaracak" epistemik bir rejim değişimi ve öncelikle rasyonalizmin inşa süreci olarak okumaktır. Doğrudan böyle değişimlere eklemlenmeyen dönüşümleri görmezden gelir. Daha önce bilmedikleri estetik beklentiler üreten, yeni bir domestisite ve yeni bir gastronomik dünya kuran, kadın-erkek ilişkilerini dönüştüren, mesirelerde özgürleşen, ayaklanan, ayaklananlara pencerelerinden sıcak su dökerek yardımcı olan kadınlar yetiştirmeye başlayan $^{6}$, hatta modern kamusallık örüntüleri icat eden sokaktaki Osmanl1larla/Türklerle ilgilenmez.

Öte yandan, tepeden inmecilik yapanların, Aydınlanma'yı topluma götürmeye çabalayanların da olağanlığın dikkate almaz. Burada küçük bir azınlığın devasa bir çoğunluğa aydınlık götürmeye çalıştığı savınıysa çok ciddiye alır. Neredeyse başka bazı toplumlarda topyekun bir Aydınlanma yaşanmıştır inancıyla yazar. Oysa ister Aydınlanma, ister modernleşme olarak tanımlansın, değişim tüm toplumlarda dar bir ortamdan başlayıp sarsakça yayılır. Monoblok bir Aydınlanma yoktur. Metropolle küçük kent ve kır, eğitimli kentliyle eğitimsiz, farklı ekonomik ve etnodinsel gruplar, farklı meslekler ve entelijensiya türleri, vs. hiçbir yerde eşzamanlı ve eşbiçimli değişmezler. Tekeli çok iyi bildiği bu historiyografik gerçeği ikinci plana atar. Aynı nedenle, Osmanlı/Türk tarihinin neden ayrıksı bir oluşum gibi yazılması gerektiği sorunsalını yanıtsız bırakır. Hemen daima bunun adeta tartışma-dışı bir temel aksiyom gibi kullanılarak işe başlanmasını öngörür. Tüm modernleşmelerin ayrıksı ve tikel olduğunu da benzer biçimde tartışma-dışı kılar. Tüm modernleşen toplumların bu yola girerken kendinden öncekileri bir biçimde örnek aldığını, yeryüzünde mutlak özgün modernliğin hiçbir yerde bulunmadığını da tartışmaz. En azından böyle bir kuramsal imkanı kullanmayı denemez. 


\section{Aydınlanma}

Belki de Tekeli'nin toplumsallığa yaklaşımı bağlamında en örnekleyici ve genelde en önemli metinlerinden biri olan "Geç Aydınlanan Bir Ülkede Erken Aydınlananların İkilemi ve Popülizm"7 şöyle başlar: "Aydınlanma insanlığın gelişmesinde en önemli dönüm noktası. Temelde insanın kendisine güvenmesini sağllyor. Bu güvenin biri diğerini besleyen iki yönü var. Bir yönü insan aklına güvendir. İnsan aklının, ister doğal, ister toplumsal olsun, gerçeği gözleyerek onun kurallarını çözümleyebileceğine ve elde edeceği bilgiler kanalıyla toplumu daha ileriye götürebileceğine inanılmaktadır. Güvenin bu birinci yönü insanlığa akılcllğg getirmiştir. Güvenin ikinci yönü ise insanın kendisini yönetebileceğine güvendir. Bu yönü de demokrasiyi getirmiştir."

Historiyografik anlamda çok tartışmalı bu yorum, "Aydınlanma" kavramını ait olduğu Batı ve Orta Avrupa'nın geç 17. ile erken 19. yüzyıl bağlamından koparıp evrenselleştiriyor. Bunun kuramsal açıdan işlenseydi önemli bir açılım üretebileceği aşikar. Sadece Avrupa bağlamında tanımlı bir epistemik değişimi dünya ölçeğinde genelleştirmek, modernliğin çoğullaşmasına benzer teorik imkanlar oluşturabilir8. En azından alternatif modernlikler, Avrupa-dışı modernlikler, "Avrupa'yı Taşralaştırmak" gibi kuramsal açılımları Aydınlanma için de üretmek mümkündür. Ancak Tekeli bunu denemiş gözükmez. Onun amacı bu devasa düşünce ailesini evrenselleştirmekten çok, bu ülkede zihnen temellük etmek olmalıdır. Zaten genelde de Tekeli ele aldığı her meseleyi, evrenselleşme potansiyeli olsa bile, Türkiye bağlamında tartışmaya öncelik verir. Onu daha geniş bir historiyografik ve coğrafi alana şamil bir fırsata dönüştürmez. Dolayısıyla, Aydınlanma'yı Osmanlı/Türk tarihinin son iki yüzyılını açıklayan bir merkezi kavrama dönüştürmekle yetinir. Nitekim, Tekeli'nin en geniş ölçüde yayılan ve popüler mecralarda da en çok benimsenen argümanı bu olmalıdır: Türkiye'de de bir Aydınlanma yaşanmiştır.

Oysa bu kadarıyla bırakıldığında, yani üzerinde Frankfurt Okulu'nun yaptığına benzer emek harcamadıkça, Tekeli'nin iyimser yorumunun ve/veya kuramsallaştırmasının Aydınlanma'yı tarihsel bağlamından koparıp yayılım alanını Türkiye'ye kadar uzatmasından konuşmak zor. Ayrıca terim sadece aklın egemenliğiyle veya duyularla algılananların akıl aracılığıyla yorumlanması mitolojisiyle açıklanamayacak kadar karmaşık uzanımlara sahip. Kaldı ki, Avrupa'da düşünce alanını rakipsiz biçimde egemenliğine aldığ 1 da söylenemez. Sadece romantizmin oluşturduğu akla güveni tereddütlü kılan aykırı düşünce güzergahı bile Aydınlanma bağlamından bağımsız sayılamaz. Kaldı ki, Aydınlanma'nın aktörleri arasında varlıkları yalnızca 
rasyonalizmle açıklanamayacak Masonlar gibi yarı-gizli örgütler, Protestanlık şemsiyesi altında yer alan onlarca mezhep gibi dinsel örgütlenmeler veya siyasal alanda Çariçe 2. Katerina ve Büyük Friedrich gibi "aydın despotlar", Winckelmann gibi sanatta Grek Antikitesi'nin aşılmazlığına inanan nostaljik sanat kuramcıları da vardır. Hatta, Aydınlanma'nın Musevi-Hıristiyan din öğretilerine muhalefet ederken -bence paradoksal olarak- Antikite'yle ilişkilenme israrı üzerinde de durulmuştur ${ }^{10}$. Dolayısıyla, Aydınlanma'nın "sıfırdan düşünmeye başlamak, sadece akla güvenmek" gibi kendi klasik ve popüler argümanları da tartışmalıdır. Ne var ki, Tekeli Aydınlanma'nın bu gibi meselelerini değil, sadece rasyonalizmini görmeyi yeğler. Rasyonalist olmayan bir düşünsellikten rasyonalizme doğru olan değişimi eksen alır.

Bu sayede Osmanlı/Türk değişim süreçlerinin eksenini oluşturan bir rasyonalizm meselesi inşa eder. Ama, onun Aydınlanma'sı Adorno ve Horkheimer' in kötümser rasyonalizmi ve Aydınlanma's1" değildir. "Aydınlanmanın Diyalektiği" ni yazan ikili, Nazi Almanyası gerçeğini yaşamış olmanın travmasıyla düşünmüşlerdi. Onların ardından Faşizm'in ve Faşist devletin modernliğinden konuşacaklar da çıacak ${ }^{12}$, "temiz" bir modern rasyonalite inancı aşındırılacaktır. Tekeli'nin rasyonalizmiyse hala umutla doludur. Belki de bu nedenle Weber'in bürokrasinin rasyonalizasyonu merkezli açıklamasına kabaca benzer. Ne var ki, Max Weber, bürokrasi kavramını modern finans ekonomisinin artan önemini, hukukun rasyonalizasyonunu, kitlesel kültürel fenomenlerin önem kazanmasını, merkezileşme ve devlet müdahaleciliğini, teknik rasyonalizasyonu, toplumsal ilişkilerde tırmanan kişisellikdışılığı ve dünyanın giderek büyüsünün bozulmasını (Entzauberung der Welt) yaşayan bir toplumun rasyonelleşmesi bağlamına yerleştirmişti ${ }^{13}$. Tekeli ise bunların hiçbirini yaşamamış (ya da yaşadığı historiyografik olarak pek anlatılmamış) bir toplumda rasyonelleşen ve rasyonelleştiren bir bürokrasi+entelijensiyanın rolünü ortaya koymayı dener. Çünkü, o toplumun yukarıda sıralananları zaten bir biçimde yaşamakta ve üretmekte olduğuna inanmaz. Dolayısıyla, rasyonelleşen pratiklerin varettiği bir Aydınlanma yerine, Aydınlatma'nın varettiği ve rasyonelleştirdiği pratikleri teşhis eder.

Sözgelimi kent planlama ona göre Aydınlanma'nın çocuğudur ${ }^{14}$. Hatta nesnel sosyal bilimin kuruluşuyla planlama düşüncesi arasında bir bağlantının varlığına da inanır. Öncesindeki dört yüzyıllık modern kent planlama eylemlerinin karmaşık tarihçesini özellikle amaçlayarak tartışma dışı bırakır. Olsa olsa kısa değinmelerle yetinir. Konu Osmanlı/Türk kent planlama alanına geldiğinde, ülkenin rasyonaliteyle açıklanması kolay kolay mümkün olmayan, hayallerin gerçeklerden daha hızlı işlemesi umularak gündeme geti- 
rilmiş planlama deneyimlerine asla sert eleştirilerle yaklaşmaz. Çelişkiler teşhis etmekten neredeyse kaçınır. Oysa, Geç Osmanlı'dan bugüne dek kent planlama Türkiye'de toplumsal ve fiziksel gerçeklikle çatışma pratikleri bütünü olarak bile nitelenebilir. Neredeyse olanaksız bir kentsel disiplin rejimi tesis etmek için uğraşmaktır planlama burada. Ne var ki, Tekeli kötümser değildir; bu gibi argümanlarla konuşmaz.

Benzer bir iyimserliği de Aydınlanma'yı demokrasiyle doğrudan bağlantılandırması olur. Ona göre akılcı davranış kaçınılmaz olarak kendi kendini yönetme iktidarındaki özgüven sahibi yurttaşı ortaya çkaracaktır. Sonucun bu iyimserliği desteklemediğini kendisi de görür. Demokrasi hiç de öyle işlememektedir. Çok sayıda makalesinde bunu anlatır ve nedenleri üzerine yazar. Ancak, Aydınlanma'nın o olumluluklar vadeden başlangıç tanımından fedakarlık etmez.

\section{Modernite Projesi}

Modernite projesi, terimi Habermas'tan ${ }^{15}$ alıntılanmış gibi gözükür. Fakat, Habermas'ın Postmodernite yazınının yeni doğduğu bir sırada yazdığı "Moderne, ein unvollendetes Projekt" (Modernlik, Tamamlanmamış Bir Proje) modernitenin sonlandığı savına yönelik bir itiraz metnidir ve modernliğin henüz çağ 1 dolmamış bir dünya-tarihsel durum olduğunu savunur. Tekeli ise modernite projesi ifadesiyle vurguyu modernitenin üzerinden kaldırır ve projenin üzerine yerleştirir. Dolayısıyla, onun Habermas'ın temin ettiği bir teorik imkanı kulllandığı veya kullanmaya çalıştığı söylenemez. Kendi düşüncesi bağlamında yaşamsal bir terminolojik aktarma yapar. Hatta, Tekeli'nin Modernite Projesi Habermas'ınkine uzaktan bile benzemez. Tekeli'ye göre Osmanl1-Türk modernleşmesi hemen daima bir dönüşme değil, dönüştürme projesidir. "Proje" kavramı ise, bir grubun (projeyi hazırlayanların) özne, diğer bir grubun da kendileri için modernleştirici proje hazırlanan nesneler olduğunu ima ediyor. Aktif ve pasif elemanlardan oluşan ikili bir toplumsallık tahayyülüdür bu. Zayıf tarihselliğe inanınca modernliğin bir proje olmaktan başka şansı yoktur da.

Modernlik, Tekeli için çok önemli ve hatta asla vazgeçilemeyen bir temel özelliğe sahiptir: O sağlam bir düzenlilik ve içtutarlılık epistemesidir. Açıkça bu şekilde hiç ifade etmese de, anladığım kadarıyla, modernlik onun için "dünya-tarihsel bir durum" değildir. Epistemik bir rejimdir. Ona olan ya da "büyük anlatılar"a olan imanını hiç yitirmez. Modernliği belirli bir zaman aralığını dolduran karmaşık, çelişkili sayısız toplumsal olgunun, uçsuz bu- 
caksız düşünme imkanlarının disipline gelmez toplamı olarak görmez. Aydınlanma' da da, modernitede de adeta mimari ve konstrüktif bir disiplinin içkin olduğuna inanır. Zaten moderniteyi proje olarak görmesi de herhalde bundan kaynaklanır. $\mathrm{O}$, adım adım bir dizi başlangıç argümanından başlayarak, temelden çatıya kadar, biri diğerini mümkün kılan ve gerekçelendiren bir ussal yapılanmaya inanır. Onun modernliği sarsak ve ihtilaçlı bir modernlik değil, projelendirilmiş ve inşa edilmiş sistematik bir modernliktir.

Ne var ki, modernliğe proje olarak bakması, projelendirme yaklaşımlarının tekil olmadığını görmesini engellemez. Dönem ve tavır farklılıklarını görür. Ancak bu kez de farklılıkları değer yargılarıyla tanımlayacaktır. Örneğin, "Osmanlı modernleşmesi 'sıkılgan' bir modernleşmedir"; "yumuşak' bir modernite projesidir"16. Erken Cumhuriyet "radikal"17, çok partili dönem "popüler" modernlikler ortaya koyacaklardır. Bunların hepsi de Tekeli'nin merkezi yönetimin kimi tercihlerine koyduğu teşhislerdir. Oysa, merkezi yönetimin iktidarı dışında kalan, yönetimin ilgilenmediği, farkına bile varmadığı, ideolojik ajandasında yer tutmayan alanların aynı sıfatlarla nitelenmesi belki de mümkün değildir. Ama Tekeli bu meseleyi araştırma menziline dahil etmez. Örneğin, 1920'ler ve '30'larda Türkiye' de "radikal” modern kapsamında ele alınabilecek bir sanatın (müzikten görsel sanatlara) mevcut olmadığını hesaba katmaz. 1950'lerden başlayarak doğan modern sanatın, popüler kültürün ve c1lız Amerikanizmin ne denli radikal değişimlerle bağlantılı olduğunu değil, dönemin iktidarının popülist tavizkar dilini dikkate alır. Tekeli belli ki, siyasal iktidarların muktedir olduğuna inanır. Bu açıdan da entelijensiyanın Tanzimat'tan başlayan "modern" tarihine eklemlenir. Yönetimin doğru ya da yanlış kararlarının, savrulmalarının, rasyonel ya da irrasyonel yaklaşımlarının varedici ve denetleyici gücüne merkezi önem atfeder. Siyasal iktidarları küçümsemez. Kuşkusuz, Tekeli'nin girmediği bir yolda ilerleyerek siyasal iktidarları küçümseyerek kuramsallaştırma ve tarihselleştirme olasılıkları mevcuttur.

Modernitenin olumlanması Tekeli'nin hiç unutmadığı bir "Leitmotiv"dir; onu sürekli gündeme getirir. Nietzsche'nin yaptığı gibi "hayır ve şerrin ötesinde"18 bir modernlik düşlemesi pek sözkonusu olmaz. Bununla modernliğin sadece değişim olarak kuramsallaştırılıp, metafizik yargılara ve ne iyi, ne de kötü şeklindeki nitelemelere imkan vermediği yaklaşımları kastediyorum. Tekeli böyle düşünmediği için, modernite eleştirisi güzergahında da hevesle ilerlemez. Ya da onun modernlik eleştirisi Alain Touraine'inkine ${ }^{19}$ benzer. $\mathrm{O}$ da Touraine gibi aklın egemenliği ve özgürlüğü modernlikle içsel bir bağlantı içinde düşünür. Ancak onun aksine, Tekeli'nin yaklaşımı kapitalist pazar 
ekonomisinin denetleyici iktidarıyla mücadele halindeki kişi ve grupların eylemleriyle varedilmiş bir başka modernlik arayışı değildir. Objektivite ve rasyonalite merkezli bir modernliktir.

\section{Bir Tavır Olarak Normatif Düşünmek}

Tekeli'nin düşünsel konstrüksiyonlarının gerçek fiziksel konstrüksiyonlara benzer olduğundan, temelden çatıya uzanarak birbiri üzerine oturan ve herbiri diğerini gerekçelendiren yapısından yukarıda söz etmiştim. Yine abartılı bir değerlendirmeyle, onun mühendislik geçmişi bu alanda bir kez daha görünürlük kazanır diyeceğim. Hemen her yazısında önce başlangıç kabullerini sıralar, sabit değerleri ve normları tanımlar, ardından da o kabul ve normların doğrulandığı çözümü ya da doğrulanmadığı açmazı sunar. Açmazdan nasıl çıkılacağını kapsamlı anlatmadığı hallerde, olası çözümü de bir anlamda ima eder. Ama kabul ve normları tartışmaz veya ender olarak tartışır. $\mathrm{O}$, metaforik bir anlatımla, matematiksel bir zihinsel kuruluşla aksiyomlardan, teoremlerden yola çıkar ve problem çözümlerine doğru ilerler. Örneğin, "kentli yurttaşın oluşamayışı" 20 gibi Türkiye'de çok etkili olmuş ve bugüne dek yaşamaya devam edecek bir normatif yargı verir: "Çevre ülkelerinde hızlı kentleşme olgusu yaşanmaya başladığında pozitivist bir toplumbilim anlayışı içinde beklenen, köylerden koparak gelen bu kitlelerin bir kültürel değişim geçireceğiydi. (...) Ama bu kent sosyolojisi yazınının beklediği doğrultuda olmadi"21.

Bu argümana itiraz edilemeyeceği aşikar. Fakat, ondan çıarılabilecek sonuçlardan biri, o kitlelerin mevcut teorik aparatlarla anlamlandırılamayan kültürel değişiminin ne olduğunu sormaktı belki de. Bu, kent sosyolojisi yazınının eleştirel bir gözle revize edilmesine yol açabilirdi. $O$ yazının üretildiği yerlerde bile geçerli olup olmadığı sorgulanabilirdi de... Tekeli, postkolonyal yazının tereddütsüz yöneldiği bu güzergaha yönelmeye niyet etmez. Bir kez daha yinelersem, başlangıç argümanlarını feda etmez. Örneğin, farklı kuramsal bir temellendirmeyle ve farklı ölçütlerle ele alınırsa, burada da farklı "kentli yurttaşlar" oluştuğu söylenebilirdi. Ya da "kentli yurttaş" gibi bir kavramın teorik gerekliliği tartışılabilirdi. Belki kentsel-toplumsal gerçekliği "kentlileşme" ve "yurttaşlaşma" kavramlarından vazgeçerek tartı̧̧mak da mümkündür. Tekeli, böyle düşünmek yerine, mevcut toplumsal ve siyasal düzende yanlış işleyenlerin, "kurala uymayanların" neler olduğunu araştırmaya koyulur. Sözgelimi, “(...) bir ülkede siyaset yapma biçimi popülizme ve 
patron-adamı ilişkilerine hapsoldu mu, yurttaşın ortaya çıkmasının olanakları kalmamıştır"22 yargısını vererek yine başlangıç argümanlarına uymayan sonuç-durumu teşhis eder.

Tekeli düşüncesinde hemen daima örtük veya yarı-örtük bırakılmış bir ideal-tip kavrayışı vardır belki de. Bazen kendisinden önce icat ve/veya tesis edilmiş ideal-tipleri kullanır, bazense yeni ideal-tipler inşa eder. Kent planlama, demokrasi, popülizm, yurttaş, rasyonalite vs. hep böyle ideal-tipler olarak tanımlanmışlardır. O nedenle, Tekeli sık sık vuku bulmakta olanları tanımlayan ideal-tipten yola çıkıp, giderek amaçlansa da vuku bulamayan durumu ortaya koyar. Örneğin, Türkiye'de demokrasinin bir türlü kuvveden fiile çıamayışı meselesi onun önemli sorunsallarından biridir. Onu da nasıl olması gerektiği önkabulünden yola çıarak açılar: "Oysa böyle kurumsallaşmış bir siyasal gücü kimin kullanacağını belirleyen araçsal bir temsili demokrasi yerine, siyasal gücün oluşmasını sağlayan bir demokrasi pratiği gelişmiş olsaydı, hem aydın böyle bir ikilemle karşılaşmayacak hem de böyle bir popülizme gereksinme doğmayacaktı." ${ }^{23}$ Yine itiraza imkan vermeyen bir argümandır karşımızda olan. Tereddütsüz katılabiliriz.

Sorun şu ki, aynı argümanın içinde gizli çok kapsamlı -dolayısıyla yayılımı Türkiye'yi aşan- "araçsal temsili demokrasi" gibi ideal-tip olarak nitelenmesi beklenecek bir ideal-tipi üretmez. Bunun nedenini anlamak zor değil: Tekeli'nin ideal-tipleri daima olumlulukla tanımlıdır. Onun ideal-tipleri karmaşık toplumsal gerçeklikleri, kurumları, davranışları yalın kalıplara indirgeyerek anlamayı denemenin teorik araçları değildir. Onun ideal-tipleri adeta mihenk taşlarıdır. Toplumsallığı Weber'vari bir vuzuhla açıklamaktan çok, ideal-tipe uymayan olguları daha bile belirgin bir vuzuhla teşhise ve tedaviye yöneliktirler. Olguların o ideal-tipe başvurularak kalibreleri, “ayar"ları saptanır. İdeal-tipin tanımladığı "olması gereken"e ne kadar yakın, ne kadar uzak oldukları belirlenir. İdeal-tip, onun düşüncesinde bir asgari zorunlu içerik listesi gibidir.

Makalenin en başındaki iddialarıma dönersem, Tekeli çözüm ister; özgül sorumluluk taşıyan bir bilim insanı kimliğiyle olanla olması gerekenin gerilimini hissetmekten bir türlü uzaklaşamaz. Toplumsallı̆̆ kuramsallaştıran biri olmakla yetinemez, onun sorumluluğunu da duyar gibidir. Ondan yanitlar beklenmektedir. $\mathrm{Bu}$, sadece farazi veya kendisine kendisi tarafından empoze edilmiş bir beklenti değildir; Türkiye'de genel olarak da bilim insanından böyle bir çözüm bulucu otorite kimliğiyle konuşması beklenir. Tekeli de kaçınılmaz olarak öyle davranır; Tanzimat'tan başlayan bir entelektüel güzergahta ilerler: Onun her "teşhis"i açık veya örtük olarak "tashih" ve "tan- 
zim"e işaret eder. Ama, ele aldığı kuramsal araçları değil, kuramın açıkladığ//yorumladığı, kendisine nesne kıldığı toplumsallığı tashih ve tanzim etmeyi önerir. Ne var ki, o güzergahta kendisinden önce yol alanların hepsinden ve eşzamanlı olarak ilerleyenlerin çoğunluğundan çok önemli bir farkı vardır: Sık sık vülger olmak durumunda kalmış “toplumsal sorumluluk sahibi ve yol gösterici düşünür" tipini o vülgerizasyonundan kurtarıp reel bir akademik zemine taşır. Ziya Gökalp'ten başlayarak gündelik siyasal pratiklere eklemlenen ve açı ya da örtük olarak siyasal iktidar talepleri dile getiren sosyal bilimler araştırmalarını ait olmaları gereken yere doğru yönlendirir. $\mathrm{O}$ müthiş çalışkanlığıyla bıkmadan usanmadan uğraştığı ve başardığı şey tam da budur.

\footnotetext{
${ }^{1}$ Osmanlı materyalizminin bu özellikleri için bkz. Şükrü Hanioğlu, "Blueprints for a Future Society: Late Ottoman Materialists on Science, Religion and Art", Late Ottoman Society:

The Intellectual Legacy, ed. E. Özdalga, Routledge, Londra, 2005, s. 28-116.

${ }^{2}$ St.-Simon'dan ve eserlerinden haberli bir Osmanlı ve Erken Cumhuriyet entelektüeli bilmiyorum. Genelde Saint-Simon ve Sensimonizm için bkz. Pierre Ansart, Sociologie de SaintSimon, PUF, 1969; François Gallice, "Les Ingénieurs saint-simoniens: Le Mariage de l'utopie et de la raison", Recherches contemporaines, no 2, Université Paris-X (Nanterre), 1994, s. 525; Pierre Musso, La religion du monde industriel: Analyse de la pensée de Saint-Simon, Editions de l'Aube, 2006; Olivier Pétré-Grenouilleau, Saint-Simon, l'utopie ou la raison en actes, Biographie Payot, Paris, 2001; Antoine Picon, Les Saint-simoniens: Raison, imaginaire et utopie, Belin, Paris, 2002.
}

${ }^{3}$ Nilüfer Göle, Mühendisler ve İdeoloji: Öncü Devrimcilerden Yenilikçi Seçkinlere, İletişim, İstanbul, ilk baskı 1986.

${ }^{4} \mathrm{Bu}$ terim ne Göle'de ne de Tekeli'de var. Ancak "zayıf tarihsellik" ifadesi kaçınılmaz olarak modernleşmeyi böyle bir zayıf zeminde yaşamayan "sağlam tarihsellik" toplumsallıklarından söz etmeyi ima ediyor. Burada "zayıf"1 varolduğuna göre, bir yerlerde de "sağlam"1 bulunsa gerek.

5 İlhan Tekeli, “Geç Aydınlanan Bir Ülkede Erken Aydınlananların İkilemi ve Popülizm”, Modernite Aşılırken Kent Planlaması, İmge, Ankara, 2001, s. 36.

${ }^{6}$ Kadınların ayaklanmalardaki rolü için: Uğur Tanyeli, "Spatiality of the Rebellions: The Female Rebels of Istanbul and Architectures of Discontent (1730-1908)", İstanbul Araştırmaları Yıllı̆̆ / Annual of İstanbul Studies, 7, 2019, s. 147-158.

${ }^{7}$ Tekeli, "Geç Aydınlanan Bir Ülkede...", s. 35.

${ }^{8} \mathrm{Bu}$ çoğullaşma imkanı için önemli bir başlangıç metni: Dilip Parameshwar Gaonkar, "On Alternative Modernities", Alternative Modernities, ed. D.P. Gaonkar, Duke University Press, 2001, s. 1-23

${ }^{9}$ Dipesh Chakrabarty, Provincializing Europe: Postcolonial Thought and Historical Difference, Princeton University Press, ilk bask 2000

${ }^{10}$ Örneğin: George E. McCarthy, Romancing Antiquity: German Critique of the Enlightenment from Weber to Habermas, Rowman \& Littlefield Publishers Inc., Lanham, MD., 1997.

${ }^{11}$ Max Horkheimer ve Theodor W. Adorno, Dialektik der Aufklärung. Philosophische Fragmente, Querido Verlag N.V., Amsterdam, ilk bask1 1947.

12 Örneğin Faşizm'in modernizmle ilişkisi için: Roger Griffin, Modernism and Fascism. The Sense of Beginning under Mussolini and Hitler, Palgrave Macmillan, 2007 
${ }^{13}$ Carlos Miguel Ferreira ve Sandro Serpa, "Rationalization and Bureaucracy: Ideal-Type Bureaucracy by Max Weber", Humanities \& Social Sciences Reviews, Vol 7, No 2, 2019, s. 188 14 İlhan Tekeli, "Bir Modernite Projesi Olarak Türkiye'de Kent Planlaması", Modernite Aşılırken Kent Planlaması, İmge, Ankara, 2001, s. 9 vd.

15 1980'de Adorno Ödülü törenindeki konuşmadan başlayarak sayısız kez basılmış bu metnin kitapçık formatındaki hali: Jürgen Habermas, Die Moderne, ein unvollendetes Projekt, Reclam, Leipzig, 1994.

${ }^{16}$ Tekeli, "Bir Modernite Projesi Olarak...”, s. 22.

17 İlhan Tekeli, "Modernist Meşruiyet Çerçevesinin Yetersiz Kalışının Bir Örneği Olarak İstanbul'un İkinci Dünya Savaşı Sonrasındaki Büyüme Öyküsü”, Modernite Aşılırken Kent Planlaması, İmge, Ankara, 2001, s. 74.

${ }^{18}$ Friedrich Nietzsche, Jenseits von Gut und Böse. Vorspiel einer Philosophie der Zukunft, Leipzig, ilk basim 1886.

${ }^{19}$ Alain Touraine, Critique de la modernité, Fayard, Paris, ilk bask1 1992

${ }^{20}$ İlhan Tekeli, "Popülist Politikalar, Kentsel Rant Ekonomisi ve Vatandaş Oluşturmayan Kentleşme Deneyi”, Modernite Aşılırken Kent Planlaması, İmge, Ankara, 2001, s. 45-56.

${ }^{21}$ a.e., s. 50-51

22 a.e., s. 52

${ }^{23}$ Tekeli, "Geç Aydınlanan Bir Ülkede...”, s. 44. 